\title{
In the
}

Welcome to the December 2021 issue of C\&RL News. This issue begins with the latest installment of our Perspectives on the Framework column. Brittany O'Neill of Louisiana State University discusses her efforts at empowering students to navigate privilege in publishing through the "Authority is Constructed and Contextual" frame.

At Lafayette College, librarians worked at "Building a digital repository of assignments" for increased instructional collaboration across campus. Tracie Marcella Addy, Bianca Falbo, and Lijuan Xu detail the development and execution of the project, which began with a group of first-year seminar courses and expanded to a campus-wide initiative.

In this month's Scholarly Communication column, Retno Sayekti of the Universitas Islam Negeri Sumatera Utara Medan in Indonesia explores "Applying the concept of rahmatan lil alamin in publication."

Adam Chalmers of the University of North Florida provides a step-by-step outline of his library's effort at "Getting up and running with virtual reality" through the transformation of physical space into a hybrid VR and library instruction classroom.

According to tradition, we also take a look back at ACRL's accomplishments in advancing learning and transforming scholarship with our 2020-2021 Annual Report. You can help make the next year of your association as successful as the last by volunteering to serve on an ACRL committee or editorial board The call for volunteers is available on page 509 .

Make sure to check out the other features and departments this month, including a The Way I See It essay from Cynthia A. Romanowski as she continues documenting her journey to tenure as a "First-time faculty librarian" and information on the Public Service Loan Forgiveness Program in the latest edition of Washington Hotline by Kevin Maher.

Thanks as always for reading the News! —David Free, editor-in-chief, dfree@ala.org

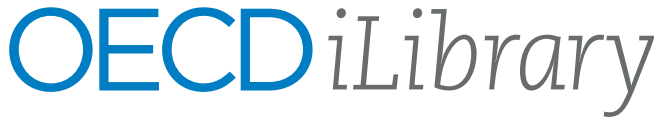

We are proud to have received the Choice Outstanding Academic Title award for OECD iLibrary platform. In awarding Outstanding Academic Titles, the editors apply several criteria to reviewed titles:

- Overall excellence in presentation and scholaship

- Importance relative to other literature in the field

- Importance in building undergraduate library collections

Join over 2500 subscribing institutions, and a community of $7 \mathrm{~m}$ users in 100 countries

Explore the OECD iLibrary now!

www.oecd-ilibrary.org

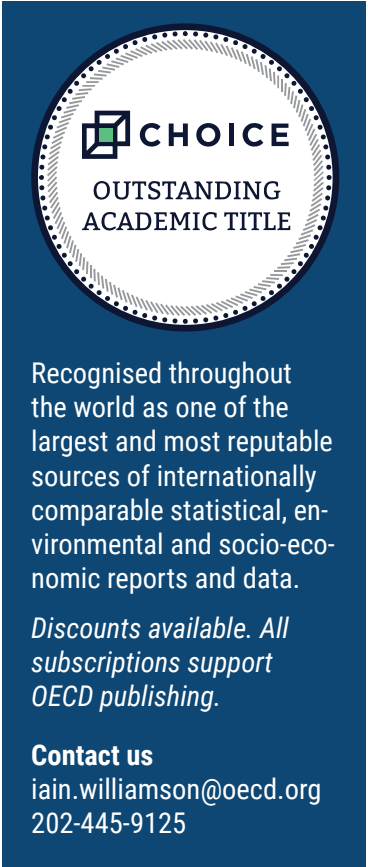

